\title{
Turecko, kurikula, slzný plyn: Evropská konference pedagogického výzkumu 2013
}

\author{
Istanbul, 10.-13.9. 2013
}

V roce 2013 byla hostitelem Evropské konference pedagogického výzkumu Bahçeșehir Universitesi v Istanbulu. Konference se odehrávala v př́jemném moderním kampusu této privátní školy přímo na břehu Bosporu na dohled od mostu spojujícího Evropu a Asii. Univerzita, která nabízí bakalářské, magisterské i doktorské programy a kde výuka na všech devíti fakultách probíhá v angličtině, má současně „kampusy“ $\checkmark$ mnoha zemích celého světa a z jejích 14 tisíc studentů asi tisícovka pochází ze zahraničí ( $v$ tomto ukazateli v Turecku vede). Tradice univerzity $v$ oblasti pedagogiky je sice krátká (pedagogická fakulta je v rámci školy nejmladší), ale univerzita je součástí skupiny provozující i školy nižších stupňủ, testující žáky apod., takže staví na značných zkušenostech se vzděláváním a využívá sít' kontaktů v této oblasti. Příprava učitelů na pedagogické fakultě Bahçeșehirské univerzity klade důraz na systém praxí doma i $v$ zahraničí, díky kterému již během studia vznikají vazby mezi budoucími učiteli a konkrétními školami. (Uvedená vzdělávací skupina, největší v Turecku, si tak asi připravuje vlastní budoucí personál.) Univerzita tak ilustruje celosvětový trend - vstup nových nestátních hráčů do školství i do pedagogického výzkumu ( $v$ oblasti vzdělávací politiky se na konferenci mluvilo o exo-demokratických aktérech).

Než upozorníme na některé zajímavé obsahové momenty konference, několik informací o tureckém školství. Podobně jako celá turecká společnost i turecký vzdělávací systém prožívá v posledních letech dramatické změny. $V$ oblasti základního školství se řada z nich jeví pozitivně - např. mezi lety 2003 a 2009 se v každé ze tří hlavních disciplín sledovaných šetřením PISA zlepšil průměrný výkon tureckých žáků nejméně o dvacet bodů. Současně se zmenšily rozdíly mezi žáky, nebot' zlepšení výsledků u skupiny nejslabších žáků bylo výraznější. Došlo i k zvýšení podílu mladých lidí, kteří jsou ve věku 15 let ještě ve škole.

Tento pozitivní vývoj je podle analýz Světové banky (Promoting excellence, 2013) dán především dvěma faktory: 1 . celkovým zlepšením socioekonomické situace v Turecku a 2. zvýšením efektivity vzdělávacího systému. Podle Světové banky se na jedné straně díky hospodářskému rozvoji zvýšila životní úroveň obyvatel, ale na druhé straně má dnes $v$ Turecku socioekonomický status žákovy rodiny menší vliv na jeho výsledky $v$ šetření PISA, což naznačuje, že se zvýšila efektivita vzdělání poskytovaného prakticky celé populaci.

$\checkmark$ roce 1997 byl přijat zákon, který prodloužil povinnou školní docházku na osm let, což vedlo $\mathrm{k}$ bezprecedentnímu rozvoji školství včetně budování infrastruktury 
(výstavba a renovace škol, vybavení pomůckami a ICT) a posílení učitelského sboru, díky čemuž poklesl za posledních deset let průměrný počet z 27 na 21 žáků na učitele. V posledních deseti letech také proběhla reforma kurikula primární i sekundární školy. Velká pozornost je věnována zvyšování kvality učitelů včetně jejich počátečního a dalšího vzdělávání i kariérního rưstu, mj. je řešen problém personální situace škol v rurálních a odlehlých oblastech: noví učitelé do těchto škol nastupují na umístěnky, resp. za službu v těchto školách získávají „,body“, které jim umožňují si později vybrat školu dle své volby. Překonání izolovanosti učitelů v odlehlých oblastech je dosahováno prostřednictvím využívání moderních komunikačních technologií. Zavádění technologií do vzdělávání je tak provázáno s dalšími opatřeními charakteru organizačního a institucionálního - nejde jen o to zavést do tříd počítače a interaktivní tabule, ale především se ICT využívá pro dosažení lepší informovanosti a větší akontability systému. Žákům, rodičům, učitelům, pracovníkům státní správy i široké občanské veřejnosti je tak k dispozici několik celostátních sítí či on-line služeb, které mj. podporují školskou administrativu (evidence a sledování žáků a studentů po dobu celé jejich školní docházky až po terciární úroveň); usnadňují komunikaci rodičů se školou (informace o akcích, rozvrzích, docházce, známkách aj.) a komunikaci rodičů a další veřejnosti se státní správou ve školství. V neposlední řadě jde o platformy pro distanční a celoživotní vzdělávání obsahující on-line vzdělávací materiály pro rưzné stupně vzdělávání.

Přes uvedené úspěchy tureckého školství samozřejmě přetrvávají problémy. Za jeden z hlavních je považována velká diverzita vyššího sekundárního vzdělávání spolu s highstake testy na přechodu z nižší do vyšší sekundární školy. Pokud se podíváme na absolutní hodnoty průměrných výsledků tureckých žáků v šetření PISA, je stále ještě zhruba čtyřicet bodů za průměrem zemí OECD (což je ekvivalent jednoho roku školní docházky). Na druhou stranu analýza Světové banky upozorňuje, že pokud je průměrný výsledek zemí ve třech disciplínách očištěn od vlivu socioekonomického statutu rodin žáků i hrubého domácího produktu na hlavu dané země, pak se v takto přepočteném ukazateli Turecko zařadí na první místo mezi všemi zeměmi světa (a předstihne i Jižní Koreu). Lze tedy $v$ jistém smyslu říci, že turecký vzdělávací systém je v současnosti nejefektivnější na světě ve využívání podmínek, které mu společnost nabízí.

Pokud jde o vlastní konferenci, za nejpřínosnější považuji jednání v sekcích ( $v$ mém případě šlo o kurikulární sekci). Ta změnila své předchozí zúžené zaměření na inovace kurikula ve školách a nyní se hlásí více k problematice kurikula i na makroúrovni. Jako exemplární případ byla $v$ řadě příspěvků analyzována reforma kurikula ve Skotsku (Curriculum for Excellence).

V „nových kurikulech“ se učitel z někoho, kdo má předávat znalosti, mění na toho, kdo je aktérem změny. Ale jsou (chtějí být) učitelé opravdu aktéry, nebo přijetím této role mají znovu jenom realizovat agendu někoho jiného? Mohou učitelé dosáhnout opravdu aktivní role $v$ tvorbě kurikula, nebo jsou zablokováni svými pracovními podmínkami? Ekologický pohled zdůrazňuje, že učitelé vždy reagují prostřednictvím toho, co mají k dispozici ve svém prostředí. Etnografický výzkum mimo jiné zjistil 
nedostatek odborného jazyka, diskurzu, který by učitelům umožňoval kritický odstup od vzdělávací politiky. Přinejmenším na rétorické úrovni učitelé akceptují reformu, ale jejich vyučování je ovlivněno hlubšími představami o roli učitele, pojetími žáka. Každopádně „nová kurikula“ mohou být příležitostí pro obnovení výzkumu kurikula.

I když se kurikulární príspěvky soustřed'ovaly především na anglicky mluvící země, v diskuzi bylo konstatováno, že jejich závěry do značné míry odrážejí i situaci v dalších oblastech (Japonsko...), a pozornost byla věnována i vývoji a reformám národního kurikula či odpovídajících kurikulárních rámců např. v hostitelském Turecku, Švédsku aj.

Další zemí, kde reformy více méně kopírují vývoj v anglosaském světě, je Německo, které přechází od tradičního řízení na vstupu (kurikula, finance, vzdělávání učitelů) k řizení na výstupu (výkonové standardy, měření kompetencí, kompetenčně orientované výstupní zkoušky). Mísení tradičních a nových forem řízení ve střední Evropě vede $k$ nežádoucím vedlejším efektům. I když v Německu nebyla vưči standardům vyloženě negativní reakce, kritika se týkala mj. toho, že probíhá př́liš mnoho reforem současně nebo $v$ rychlém sledu za sebou. Související problematikou měření na úrovni německého povinného i terciárního vzdělávání se současně z rưzných pohledů zabývalo několik př́spěvků. Velkým tématem jsou kompetenční modely jako nástroj pro racionální tvorbu kurikula a především jako podklad pro konstrukci měřicích nástrojů (testů).

$\checkmark$ této sekci jsem také pronesl př́spěvek „Massive Decline of Czech Pupils’ Achievement: Did Curriculum Contribute?“, který vzbudil zájem zejména kolegů z postsocialistických zemí, kteří mají podobnou zkušenost s tím, jak jejich učitelé získali možnost vytvářet kurikula, ale nebyli pro to připraveni (,šoková profesionalizace učitelů“).

Jako tradičně se konaly $v$ průběhu konference pracovní setkání tematických networků, kterých $v$ současnosti v rámci EERA pracuje třicet (na istanbulské konferenci se prezentovaly např. nový network environmentálního vzdělávání a výchovy k udržitelnosti a network zaměřený na jazyky a vzdělávání). Networky hrají $\checkmark$ př́pravě konference klíčovou roli, protože odpovídají za sestavení programu př́slušné tematické sekce. Relativní inovací v letošním programu konference byla větší spolupráce mezi networky, která vedla $\mathrm{k}$ vyššímu počtu zasedání společných více sekcím/networkům.

Hlavnímu programu předcházela tradiční doktorská konference, které se účastnila řada účastníků z České republiky. V posterové sekci byla z hlediska kvantity i kvality důstojně zastoupena česká pedagogika díky mladším výzkumníkům. Doktorand Jakub Pivarč z Pedagogické fakulty UK získal ocenění za jím prezentovaný poster.

Úspěšné uspořádání velké mezinárodní konference na moderní univerzitě dokládá oprávněnost sebevědomí turecké společnosti, ambice jejích rychle rostoucích vzdělaných vrstev i jejich zájem o propojení s evropskými strukturami. Slunné zářijové dny v Istanbulu ovšem poněkud kazilo vědomí, že v sousední Sýrii zuří občanská válka. Na dohled od místa konání konference jsme se navíc denně potkávali se silně 
vyzbrojenými oddíly speciálních policejních sil připravených zasáhnout v případě demonstrací, které probíhaly (a byly tvrdě potlačovány) $v$ Turecku $\vee$ předchozích měsících. Turecko (odkud je to mimochodem blízko i na Krym) asi nečekají jen slunné dny.

Poděkování: Moje cesta na ECER 2013 byla umožněna Českou školní inspekcí $\checkmark$ rámci projektu Kompetence I, spolufinancovaného Evropským sociálním fondem a státním rozpočtem České republiky.

\section{Literatura}

Promoting excellence in Turkey's schools. (2013). Washington: World Bank.

Dominik Dvořák dominik.dvorak@pedf.cuni.cz 